\title{
Development of E-learning Software Based Multiplatform Components
}

\author{
Irma Salamah*, M. Aris Ganiardi \\ Electrical Engineering, State Polytechnic of Sriwijaya, Jalan Srijaya Negara Bukit Besar \\ Palembang 30139, Indonesia \\ *Corresponding author, e-mail: irma.salamah@yahoo.com, marisg2010@gmail.com
}

\begin{abstract}
E-learning software is a product of information and communication technology used to help dynamic and flexible learning process between teacher and student. The software technology was first used in the development of e-learning software in the form of web applications. The advantages of this technology because of the ease in the development, installation, and distribution of data. Along with advances in mobile/wireless electronics technology, e-learning software is adapted to this technology known as mobile learning. The ability of this electronic device is the same as a single computer even though it is simpler than a single computer. The problem that arises when e-learning software operates on multiple platforms is that computer programs are made repeatedly depending on the platform being used. This situation will obviously affect the quality of e-learning software. To overcome these problems, in this study developed component-based software that is a modern paradigm for software development that produces reusable software components, high quality, and cost-effective. In software development, software components will be assembled in the software in need. The result of this research is high quality e-learning software based multiplatform component.
\end{abstract}

Keywords: E-learning, web application, mobile learning, component software

\section{Introduction}

One of the information and communication technology products used for teaching and learning process is e-learning. Implementation of e-learning in an educational institution involving internet technology media, tv cable, satellite software, multimedia, audio, and video [1]. According to [2] there are four forms of e-learning activity: Individualized self-paced elearning online, Individualized self-paced e-learning offline, Group-based e-learning synchronously, Group-based e-learning asynchronously. Utilization of web applications as a learning media in e-learning system increasingly large, along with the rapid development of web technology. Initially the web apps were static less desirable in the use of e-learning system, but after developed developed web 2.0 technology then the use of web applications on e-learning system more rapidly [3]. The concept of content in web applications of e-learning systems is known as Content Management System (CMS) [4]. With the CMS, the user of the web application only to customize the contents of the application in accordance with the needs. Since the development of wireless internet the use of mobile/wireless electronics devices is no longer limited to communication tools but used for internet needs [5].

The flexibility of e-learning software that is able to operate in many electronic devices (multi-platform) requires some form of software architecture that can simplify software developer e-learning. Development software component-base is a form of modern software development that is able to produce a software that is easily reusable, high quality, and save time. The focus of this research is to develop software that is able to operate in many electronic devices without neglecting the quality of the software itself.

The problems that arise in the use of e-learning software is a multi-platform software development requires huge resources that are not effective and efficient. The computer program created by the environment of electronic devices where the program operates. Each of these electronic devices have different operating systems. Characteristics of computer programs that operate on the computer in the form of different web applications with computer programs in the form of mobile. 
One programming paradigm that is able to adapt to the amount of user needs is a software development component-based. The software components is a new paradigm in programming and software development. The principle of this paradigm is modularisation computer program codes which form a special specification which later called the component. Furthermore, these components are assembled into software that requires specification of the component. Characteristic of a component is having interface which will be used as a medium of communication between components. [8] gives two definitions of software componenets as follows:a. The software components are binary units are made independently, acquisition, and distributed in a lot of software to fulfill the functional software.b. A software component is a unit of composition with the specifications fixed and made no dependent each other. A software component can be created independently created by a third party.

The role of research in the field of computer science even more contribute to the elearning systems such as the development of machine learning (machine learning) based learning case (Case Base Learning), learning systems intelligent (Intelligent Tutoring System) [6], and mobile learning [7]. Research on the Relevance of Computer Based Computer Vocational Skills SMK and Industry Students [9] and Strategy of Learning and Mechanical Talent on CNC Machine Skills [10] provide information on the fact that computer-based learning is more learning to improve intellectual skills than Physical skills. In addition, computer-based learning can be implemented with e-learning learning model to save the procurement of computer-based production equipment in educational institutions. [11] study on the evaluation of ICT-based learning in SMA and [12] study on the effectiveness of learning with the help of internet in SMK in general resulted in the fact that community awareness of the use of elearning for improving learning is good, qualifications of educators, And the attitude of students is very influential on the success of e-learning. Based on these conditions and information, a study of e-learning learning model in line with the advancement of information technology where e-learning learning is made with the development of software based component that capable of operating in various electronic devices that have its own platform of web and mobile.

\section{Research Method}

Descriptive analysis is used to describe data in the quantitative form by not including decision making through hypothesis. Data are presented in descriptive form without being treated with other static analysis techniques. Descriptive analysis is used to calculate the minimum, maximum, mean, standard deviation, and total [13]. For this reason descriptive analysis is used in this study. Descriptive analysis in this study only to find out how the knowledge of students and teachers about the internet, e-learning, the frequency of Internet use, and support facilities for e-learning.

Implementation of this method by observation, questionnaires and interviews in high school 6 in Palembang. Researchers go directly to the school to conduct observations and interviews with teachers, students, and school leaders about how they utilize existing information technology in the teaching and learning process. Implementation of this method by observation, questionnaires and interviews in high school Number 6 in Palembang. Researchers go directly to the school to conduct observations and interviews with teachers, students, and school leaders about how they utilize existing information technology in the teaching and learning process.

\subsection{Functional and Non-Functional Requirements}

The results of needs analysis can we conclude, that teacher and student want web application e-learning FUOLC be simple and easy to use. As for functionality that FUOLC have as follows :

\subsubsection{Functionality Needs}

Functionality needs from system to be built as follows:

a. System can do Authentification process, that is security process that will be validate users when they want to entering the system with checking to their list that granted to entering the system.

b. System can process subject's data, either it adding, changing, or removing subject's data in system. 
c. System can process teacher's data, either it adding, changing, or removing teacher's data in system.

d. System can process student's data, either it adding, changing, or removing student's data in system.

e. System can process class's data, either it adding, changing, or removing class's data in system.

f. System can on-line 24 hours through internet network.

g. Data searching process can be done \pm 1 second in one searching.

\subsubsection{FUOLC's Business Procedure and Process}

The software that will be developed given FUOLC code. Generally business process using FUOLC divided into five (5) categories as follows:

a. Teacher and student registration

A teacher and student to be able to use FUOLC facilities have must register themselves to FUOLC first. How to register for teacher can be done with calling FUOLC's administrator via e-mail. The administrator will make a lesson content based upon the teacher's request. Student registration can be done with filling the registration form in FUOLC's front page. After the registration, student can login to the FUOLC. In student's page, there are registration subjects form. Student can follow the subjects as a subjects participant after filling registration subjects participant form.

b. Authentication and Authorization

A user will login first before get in to the FUOLC with entering NIP, NIS, password and user's level. FUOLC will do the authentication and authorization each user who logged in. The authentication and authorization results will be known the access rights for each user.

c. FUOLC's Data Management

Data management process done by administrator. The form of management data can be adding, removing, changing, and displays data of study program, teacher, student, subject, and news. Just for data management of subjects are implementation from lesson content. Subjects added to FUOLC because of teacher's request.

d. Distribution of Material Lesson

Distribution process material lesson can be done with 2 ways. The first way can be done with write down directly material lesson in material lesson's form page. The second way, teacher can up-load material lesson's file. Maximum size up-loaded file are 5MB. Rationing of material lesson based on subjects used by the teacher. Student can download material lesson file, material lesson form in lesson content that followed by the student.

e. Tasks Collecting

Teacher can give tasks to student through the lesson announcement form. Student can collect tasks through the FUOLC student tasks form. Maximum size up-loaded file are 5MB. Files student tasks can be downloaded by the teacher in student tasks list according to the tasks content categories.

f. Lesson Information's Media

Administrator and teacher can give information related with the using of FUOLC. Administrator can give new that related to the academic activity in SMA N 6. Teacher can give announcements such as lessons cancellations or additions, giving and collecting tasks, or there are material lesson that just uploaded.

\section{Results and Analysis}

Developed e-learning's software based on multiplatform component given FUOLC code. Results obtained from the developed e-learning's software cycle using spiral mode. Table 1 show student's statistic deskriptif.

Table 1. Student's Statistic Deskriptif

\begin{tabular}{|c|c|c|c|c|c|}
\hline & $\mathrm{N}$ & Minimum & Maximum & Mean & Std. deviasi \\
\hline Pemahaman & 165 & 22.00 & 47.00 & 33.8727 & 5.41921 \\
\hline Pengetahuan & 165 & 22.00 & 40.00 & 33.2545 & 3.88345 \\
\hline Valid N (listwise) & 165 & & & & \\
\hline
\end{tabular}

Bulletin of EEI Vol. 6, No. 3, September 2017 : $228-234$ 
From the results of questionnaires given to students of SMAN 6 and SMAN 10 (165 samples) it appears that few students have laptops, rarely use the internet, and do not know elearning.From the results of data processing seen only $33.87 \%$ of students who have an understanding of the internet, and $33.25 \%$ who have knowledge about the internet. Table 2. show teacher's statistic deskriptif.

Table 2. Teacher's Statistic Deskriptif

\begin{tabular}{cccccc}
\hline & $\mathrm{N}$ & Minimum & Maximum & Mean & Std. deviasi \\
\hline Pemahaman & 37 & 11.00 & 40.00 & 29.2162 & 6.64637 \\
Pengetahuan & 37 & 29.00 & 40.00 & 33.7568 & 3.13054 \\
Valid N (listwise) & 37 & & & & \\
\hline
\end{tabular}

From the results of the questionnaires given to teachers of SMAN 6 and SMAN 10 (37 samples) it appears that few teachers have laptops, rarely use the internet, do not know what elearning is, and still do the teaching-learning process conventionally. From the results of data processing seen only $29.21 \%$ of teachers who understand the internet, and $33.75 \%$ who have knowledge about the internet.

\subsection{Use Case Diagram of E-Learning's Software}

Use case diagram in Figure 1 shows interaction between actor and e-learning's software. There are 3 factors interact with FUOLC, which are Administrator that have the responsibility with all the system, teacher and student as FUOLC main users, and visitors who have rights just to see the front page of FUOLC. Forms of interaction between actor and FUOLC are implementations of functionality needs from teacher and student.
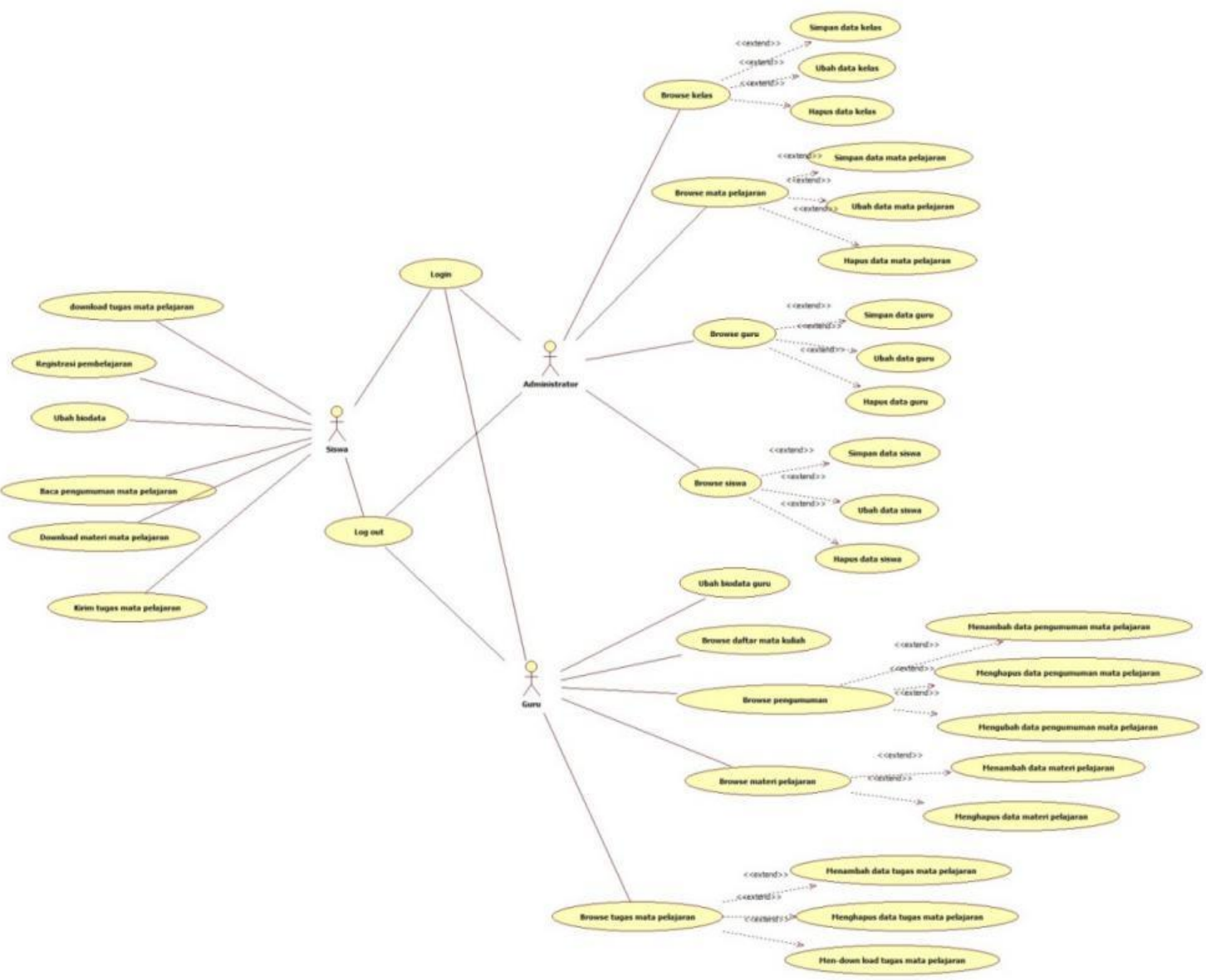

Figure 1. Use case diagram 


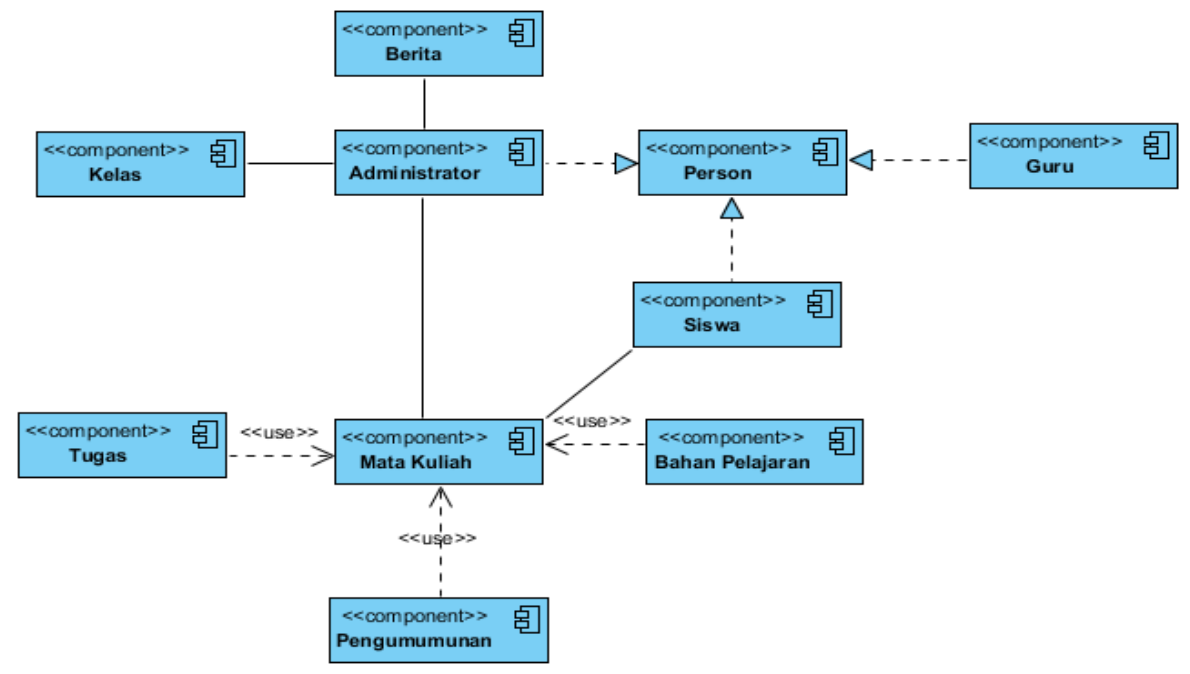

Figure 2. FUOLC's component diagram

\subsection{E-learning' Software Architecture}

FUOLC architecture consists of 2 main elements where is show in Figure 3, which is EJB element and web element. In EJB element, there are entity package consisting of entity component owned by FUOLC. Entity component program decrypting specification of FUOLC entities. Second package that owned by EJB element is model package containing component that connected to the database. Each data that needed, FUOLC will activate components model. The second main element that owned by FUOLC are web element. In this element, there are 2 package that is controller package which have function to arrange data flow in FUOLC and web package that contain FUOLC's interface components. Figure 3 explain FUOLC's component diagram

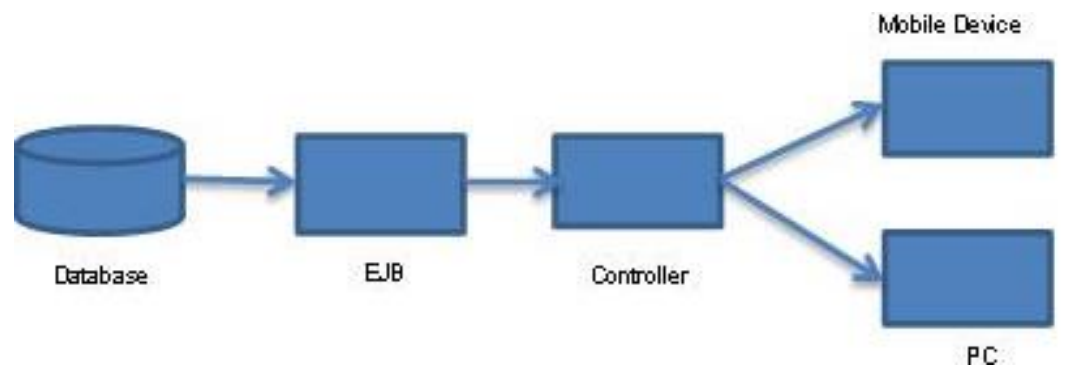

Figure 3. FUOLC's Architecture

FUOLC e-learning's software can accessed by various electronic devices such as computer and mobile devices (tablet and smartphone). When FUOLC accessed by the computer, the FUOLC's interface display will adjust with the mobile device screen. FUOLC's interface adjusting won't make FUOLC's interface layout become uncomfortable used by the teacher and student.

Data flow and actions in FUOLC will be arranged by the components controller. If the data needed it is in database, the component controller will contact the component model. Then component model will send the data to the component controller.

Last, interface component will display data in FUOLC interface, according to the teacher and student's needs.

E-learning's software based on FUOLC component testing done by the reusability and maintainability quality factor. Table 3 show detail e-learning's software test results based on fuolc's multiplatform component using maintainability and reusability quality factor. How to tests done with checking FUOLC computer's program codes based on sub-factors measurement of 
both factors quality. Figure 4 show detail piece of code FUOLC's entity component. Based on McCall's model, maintainability quality factor have 6 sub-factor qualities that can be used to know that quality factor, that is: simplicity, modularity, coding and documentation, self descriptiveness, consistency, and document accessibility. Sub-factor that owned by the reusability quality factor there are seven sub-factor, that is: modularity, document accessibility, software system independence, self descriptive, generality, and simplicity. Based on testing that have done with FUOLC using second sub-factor of quality factor, we can get a results that FUOLC fulfill all of the reusability and maintainability sub-factors. Figure 5 show Analysis results done to FUOLC can resolve needs changing or teacher and student that is large and variative.

Table 3. E-learning's Software Test Results Based on FUOLC's Multiplatform Component Using Maintainability and Reusability Quality Factor

\begin{tabular}{|c|c|c|}
\hline Quality Factor & Sub-Factor Quality & FUOLC \\
\hline \multirow{6}{*}{ 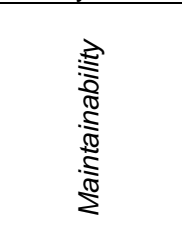 } & Simplicity & * \\
\hline & Modularity & * \\
\hline & Coding and & * \\
\hline & Documentation & * \\
\hline & Consistency & ${ }^{*}$ \\
\hline & $\begin{array}{l}\text { Document } \\
\text { Accessibility }\end{array}$ & * \\
\hline \multirow{8}{*}{ 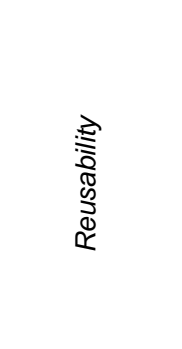 } & Self Descriptiveness & * \\
\hline & Modularity & * \\
\hline & $\begin{array}{c}\text { Document } \\
\text { Accessibility }\end{array}$ & * \\
\hline & $\begin{array}{l}\text { Software System } \\
\text { Independence }\end{array}$ & * \\
\hline & $\begin{array}{l}\text { Application } \\
\text { Independence }\end{array}$ & * \\
\hline & Self Descriptive & * \\
\hline & Generality & * \\
\hline & Simplicity & * \\
\hline
\end{tabular}

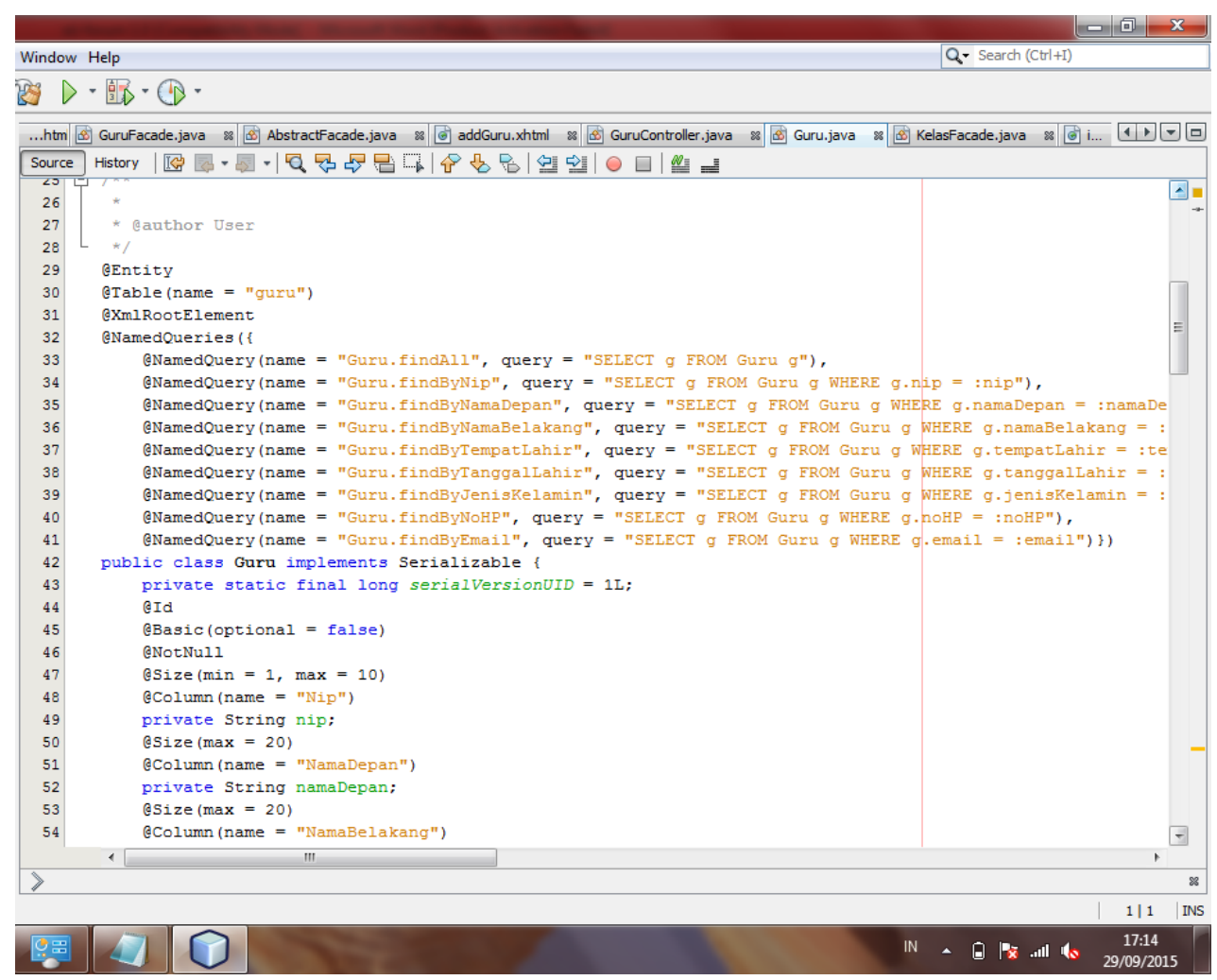

Figure 4. Piece of code FUOLC's entity component 


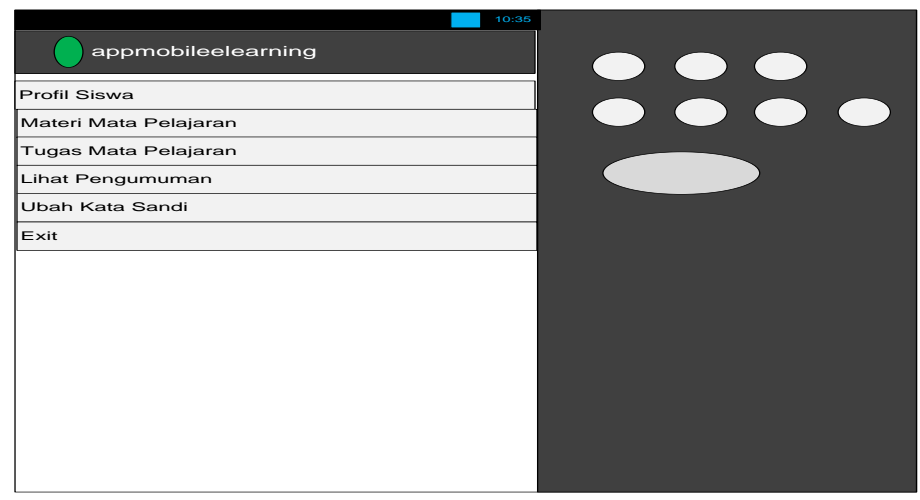

Figure 5. Android view

\section{Conclusion}

The development of software based component is a form of modern software development capable of producing a software that is easy to re-use, high quality, and timesaving. The flexibility of e-learning software capable of operating in many electronic devices (multi platform) requires a form of software architecture that enables e-learning software developers. FUOLC's e-learning software based on multiplatform component have a program structure that simple and easy to understand. Components that have been made and assembled with the other have form an integrated unity. FUOLC's e-learning software can adapt with many electronic devices who have their own platform when access it. This adaptation won't affect the data and the comfort of software using. Based on the test results, FUOLC's e-learning software have reusability and maintainability qualities. Reusability is an ability from component to re-used when there is same specification from e-learning web application. E-learning's web application being efficient because program code no need to be written over and over. Maintainability is an ease owned by component to repairs if error found. Both of this quality factors helps development this FUOLC's e-learning software to anticipate the teacher and student need that changes which is big and variative.

\section{References}

[1] Nagarajan G, G Wiselin Jiji. Online Education System (e-learning). International Journal of u-and eService Science and Technology. 2010; 3( 4).

[2] Naidu Som. E-Learning A Guidebook of Priciples, Procedures and Practices. Commonwealth Educational Media Centre for Asia. 2006.

[3] Neil Crook. What are Web 2.0 Technologies and Why do They Matter. Engineering and Physical Council. 2008.

[4] Kahiigi, et.al. Exploring the e-Learning State of Art. The Electronic Journal of e-Learning. 2008; 6(2): 77-.88.

[5] Mohammed Ally. Increasing Access through Mobile Learning. Commonwealth of Learning and Athabasca University Vancouver. 2014.

[6] Jaidan Jauhari, Mohammad Ibrahim. Intelligent Tutoring System Sebagai Upaya Inovatif dalam Pembelajaran Untuk Pembelajaran Berbantuan Komputer. Jurnal Generic. 2010; 5(2): 1-6.

[7] Carina Paine Schofield, Trudi West, Emily Taylo. Going Mobile in Executive Education. Ashridge, UK. 2011.

[8] Szyperski C. Component Software-Beyond Object Oriented Programming. Boston, USA. 1999.

[9] Bruri Triyono M Relevansi Keterampilan Mesin Berbasis Komputer Siswa SMK dan Industri. Tesis: PPs UNJ Jakarta. 1997.

[10] Bruri Triyono M. Strategi Pembelajaran dan Bakat Mekanik terhadap Keterampilan Mesin CNC. Prosiding Seminar Nasional PPs ITS Surabaya. 2009.

[11] Ferdinand S Leuwol. Evaluasi Manajemen Pembelajaran Berbasis ICT di SMA se kota Ambon. Tesis: PPs UNY Yogyakarta. 2008.

[12] Rasyid Hardi Wirasasmita. Keefektifan Pembelajaran Berbantuan Internet di SMk Muhamammadiyah Yogyakarta. Tesis: Program PPs UNY Yogyakarta. 2009.

[13] Duwi Priyatno. Paham Analisa Statistik Data dengan SPSS. MediaKom, Jakarta. 2010. 